\title{
The Concept of Deradicalization Of Terrorism In The Criminal Jurisdiction System In Indonesia
}

\author{
Jonathan Hasudungan \\ \{jonhutagalung@ hotmail.com\} \\ Doctor of Law, Universitas Jayabaya, Jakarta, Indonesia
}

\begin{abstract}
Deradicalization is a popular term in countering terrorism. The current deradicalization program has not been effective since most of the terrorists are recidivists. Some factors inhibit the deradicalization program including the absence of clear regulations (blue print) related to the deradicalization program, inadequate human resources and infrastructure. This normative legal research was done using a statute approach, a case approach, and a conceptual approach. Secondary data that consisted of primary legal materials, secondary legal materials, and tertiary legal materials were analyzed using qualitative normative analysis method. The results showed that the application of the concept of deradicalization to perpetrators of criminal acts of terrorism in Indonesia after the issuance of Presidential Decree number 46 of 2010 concerning the National Agency for Combating Crime of Terrorism has been conducted. However, this program has not resolved the root problem that is to lower the rate of radicalism. Radicalism needs to be eradicated because radical movements and thoughts of individuals and groups often lead to radical activities, such as violence, war and terror. Deradicalization program against perpetrators of criminal acts of terrorism in Indonesia has to be seriously implemented regarding the fact that criminal acts of terrorism are getting rampant through false religious teachings.
\end{abstract}

Keywords: Deradicalization, Radicalism, Terrorism

\section{Introduction}

The Indonesian terrorism prevention has not been able to eliminate the deviant religious teachings that have resulted in radicalism on behalf of religion. The influence and development of deviant religious teachings is a threat that must be anticipated by the state (the government). Recently, threats based on transnational ideology [1] have entered through the penetration or infiltration of culture and religion. Transnational religious ideology calls for revolutionary changes to establish a country based on its religious understanding.[2]

Terrorism, which is an extraordinary crime, requires extraordinary efforts. All government and private agencies must focus on their respective roles in dealing with terrorism and increasing broad cooperation from all levels of society.[3] In the case of the government, the effort is manifested by developing a deradicalization program.[4] Deradicalization has become popular in the counter-terrorism cycle, which can also mean a counselling process that aims to modify the interpretation of religious texts, avert or disengage someone from certain jihadi groups, or support the rehabilitation and reintegration of terrorist prisoners into society.[5]

Deradicalization reverses the radicalization process that starts from recruitment, selfidentification, indoctrination, and misguided understanding of jihad. By contrast, the process of deradicalization starts from the identification and classification of convicts and ex-convicts, 
focusing on integrated management, with a humanist approach, soul approach and de-ideology, multiculturalism, and independence.[6]

The results of the initial investigation and the investigation of the bombing that occurred in Thamrin Street, Jakarta, on January 14, 2016, and the bombing that occurred in Melayu Village on May 24, 2017, showed that the perpetrators were the members of The Jamaah Ansor Daulah (JAD): Sunakim (former terrorist convict), Mohammad Ali (JAD network) and Yayat Cahdiat (former terrorist convict). The two first persons are the perpetrators of the bombing in Thamrin Street, while the last one is the perpetrator of the bombing in Melayu Village. They are affiliated with one group led by Aman Abdurrahman. Aman Abdurrahman, Sunakim, and Yayat Cahdiyat are examples of deradicalization programs that are less than optimal in their implementation. It can be understood that the deradicalization program is not following what is expected.

The current condition shows that the deradicalization program that has been carried out so far has not been effective, considering that most of the perpetrators of terrorism are recidivists. Some of the obstacles in implementing the deradicalization program are the absence of clear regulations related to the deradicalization program and the lack of human resources and infrastructure related to the program's implementation.

\section{Research Methods}

The approach in this research is legal synchronization using a comparative approach, both vertically and horizontally. Vertically, this research compares Islamic law to state law. Horizontally, this research compares national law to the laws of other countries, namely Singapore.

In addition to using a comparative approach, this study also uses the statute approach, case approach, conceptual approach, and historical approach. The method used in normative legal research is statutory approach, case approach, and conceptual approach. The data used are secondary data consisting of primary legal materials, secondary legal materials, and tertiary legal materials. Data analysis is conducted by using the qualitative normative analysis method.

\section{Research Methods}

Building a legal politics of deradicalization cannot be separated from legal politics [8]. Politics is the activity of choosing a certain social goal. The same thing applies to law, namely determining a choice regarding the objectives of the law and the methods to be used to achieve these legal objectives. Crime prevention policies or efforts are essentially an integral part of protecting society (social defence) and achieving social welfare. Therefore, it can be said that the goal of criminal policy is to protect the community from achieving social welfare [9]. As a means of tackling crime, criminal policy can take various forms. First, it can take the prevention efforts without punishment. Second, the efforts to form public opinion about crimes and disseminate the law widely through mass media. Third, using a penal facility which is often called the criminal justice system. This broadly includes the process of criminalization [10].

In the concept of deradicalization, it is necessary to regulate the identification, rehabilitation, re-education, and resocialization in more detail, as stated by Agus Surya Bakti.[11]. The first is identification. It is conducted by collecting data on indicated networks to determine the development of radical movement networks, such as the number of members, 
activities, backgrounds, religious beliefs, and nationalities they profess. The second is rehabilitation. The rehabilitation program is basically a systematic effort to change the orientation of radical ideology to an ideological orientation that is inclusive, peaceful, and tolerant. The third is re-education. It is useful to transform their thoughts, understanding, and attitudes. The fourth is resocialization, and This stage is intended as an overall effort to return terrorist convicts or former terrorist convicts and their families to live and interact with the community properly.

Furthermore, to support implementing the deradicalization concept into the deradicalization program, two strategic steps were taken. First, the paradigm of radical militant groups should be changed to not return to carrying out terrorism. This implementation is carried out in synergy by involving stakeholders, such as religious leaders, psychologists, academics, and practitioners, using persuasive methods. The second is by countering ideology. This strategy is aimed at all components of society so that the terrorist understanding and actions do not easily influence them. Practical examples of this strategy are anti-radicalism training for mass organizations and training of trainers for members of religious education institutions [12].

Strategic steps in the implementation and socialization of the deradicalization program need to be more intensive and expanded in the future. In this regard, the role of Indonesian civil society organizations is very important, considering that the social environment is the main locus for spreading the seeds of radicalism. By involving the public/civil society, implementing the deradicalization program will be more effective in the long term. It is urgent to develop concepts that are compatible with the pluralistic social realities in this country and adequate as a product of public policy that is flexible enough to anticipate changes in the strategic environment that is always open. The consequence is that the deradicalization program that is MSI role-oriented will involve many stakeholders, both at the state officials and the community level [13].

Based on the above analysis supported by legal materials, implementing the concept of deradicalization in Indonesia is very appropriate to use the benefit theory (maslahah) proposed by Naj al-Din Al-Tufi that is very relevant and does not conflict with other supporting theories. The concept of deradicalization of perpetrators of terrorism in Indonesia since Presidential Decree number 46 of 2010 concerning the National Agency for Combating Criminal Acts of Terrorism has been running.

However, its implementation has not touched the root of the problem, namely efforts to decrease radicalism. This radicalism needs to be anticipated because the movements and thoughts of individuals and groups are oriented towards radical activities, such as those that lead to violence, war, and terror, which are very dangerous for humankind. The deradicalization program for criminal acts of terrorism with the deradicalization program model and existing legal materials is in line with the benefit theory and very relevant in perpetrators of criminal acts of terrorism after experiencing judicial processes and convictions. Therefore, the implementation of the deradicalization program for criminal acts of terrorism can be conducted through the investigation, prosecution, and trial process.

\section{Conclusion}

The implementation of the deradicalization concept to perpetrators of terrorism in Indonesia since the issuance of Presidential Decree number 46 of 2010 concerning the National Agency for Combating Criminal Acts of Terrorism has been running but has not touched the root of the 
problem, namely efforts to decrease radicalism. The deradicalization model that prioritizes legal benefits is countering terrorism, preventing radicalism, comparing understanding, avoiding hate provocation and hostility in the name of religion, preventing society from indoctrination, and community participation in rejecting terrorism.

The government and the wider community should support the current deradicalization program. The benefits obtained from the deradicalization program are countering terrorism, preventing radicalism, comparing understanding, avoiding hate provocation and hostility in the name of religion, preventing people from indoctrination, and community participation in rejecting terrorism. The panel of judges considers benefits related to the criminal justice process in deciding cases of perpetrators of terrorism who have participated in the deradicalization program during the investigation, prosecution, and trial processes. The importance of the concept of deradicalization in implementing a deradicalization program for perpetrators of terrorism in Indonesia is since the crime of terrorism is rampant. Such is the strengthening of radical understanding in the name of religious teachings, even though they are contrary to religious teachings.

This research recommends for the National Agency for Combating Terrorism (BNPT) to monitor and make regulations related to the deradicalization program for perpetrators of terrorism, both who are still undergoing a trial process in a detention center and who are undergoing judicial decisions in prisons and former prisoners who have returned to society.

\section{References}

[1] Suwari, "Pengaruh Ajaran Islam Transnasional Terhadap Keutuhan Negara Kesatuan Republik Indinesia", dalam Seminar Nasional oleh Yayasan al-Kahfi Pusat, Mei 2013, Universitas Airlangga (Unair) Surabaya

[2] Abdul Chair Ramadhan, Strategi Penanggulangan Terorisme Melalui Pendekatan Nonpenal, Lisan Hal, Jakarta, 2014

[3] International Crisis Group, Deradicalisation and Indonesian Prisons, Asia Report No. 142, 2007

[4] Farid Septian, Pelaksanaan Deradikalisasi Narapidana Terorisme di Lembaga Pemasyarakatan Kelas I Cipinang, Jurnal Kriminologi Indonesia, Vol. 7 No. 1 Mei 2010,

[5] Satjipto Rahardjo, Sosiologi Hukum, Muhammadiyah University Press, Surakarta, 2002

[6] Supanto, Kejahatan Ekonomi Global dan Kebijakan Hukum Pidana, Alumni, Bandung, 2010

[7] Muladi dan Barda Nawawi Arief, Bunga Rampai Hukum Pidana, Bandung, Alumni, 1982

[8] Agus Surya Bakti. Merintis Jalan Mencegah Terorisme (Sebuah Bunga Rampai), Semarak Lautan Warna, Jakarta, 2014

[9] Wawan H. Purwanto. Terorisme di Indonesia Pasca Bom Marriott 2. CMP Press, Jakarta, 2010

[10] Petrus R. Golose. "Strategi Penguatan Hukum dan Deradikalisasi dalam Mengeliminasi Tindak Pidana Terorisme". Makalah Seminar Penanggulangan Terorisme, Lemhannas RI, Jakarta, 13 Juni 2011.

[11] Muhammad AS Hikam. Deradikalisasi: Peran Masyarakat Sipil Indonesia Membendung Radikalisme. Penerbit Buku Kompas, Jakarta, 2016 